Reprod. Nutr. Dévelop., 1980, 20 (6), 1801-1810.

\title{
Immunocytochemical detection of acrosomal damage following cold shock : loss of acrosin from the acrosomal region of ram, bull and boar spermatozoa
}

\author{
par R. A. P. HARRISON, J. E. FLÉCHON * \\ A.R.C. Institute of Animal Physiology, Animal Research'Station, \\ 307 Huntingdon Road, Cambridge CB3 OJQ, UK. \\ * Station centrale de Physiologie animale, I.N.R.A., \\ 78350 jouy-en-josas, Fronce.
}

Summary. Samples of ram, bull and boar semen were subjected to cold shock and then stained using an indirect immunocytochemical method for detecting acrosin. It was found that the shock treatment abolished staining of the acrosomal region in all but a very few cells. This finding was interpreted as a great loss of proacrosin or acrosin from damaged acrosomes. Using a fluorescent label in the system, sperm cells in both control and treated samples could be scored easily and reproducibly as « stained 》 or « unstained 》. Results using a peroxidase label were less satisfactory because staining was not as consistent.

Biochemical assessment of sperm acrosin content before and after cold shock confirmed that such treatment caused acrosin loss from the cells into the seminal plasma, but as a quantitative measure of cellular integrity the biochemical method exhibifed a number of deficiencies compared with the immunofluorescent cytochemical method.

Preliminary data are presented for semen evaluation comparing this lafter method with a « live-dead» stain.

\section{Introduction.}

Acrosomal damage has long been used as a contra-indication of sperm fertilizing ability, and the loss from the cell of an acrosomal enzyme such as acrosin would seem a good measure of such damage (Johnson, Pursel and Chaney, 1974 ; Schill and Fritz, 1975 ; Church and Graves, 1976).

However, biochemical quantitation of acrosin loss from spermatozoa presents difficulties. In the intact cell all acrosin is in an inactive zymogen form, proacrosin (Brown and Harrison, 1978) ; activation only takes place after cell disruption, and then the active acrosin produced may be wholly or partly inactivated by complexing with the several species of protein acrosin inhibitors that occur naturally in semen (e.g. Polakoski, Zaneveld and Williams, 1971). Moreover, although we have been able to show that acrosin is indeed a soluble enzyme (Harrison, Fléchon and Brown, 1981), measurement of its loss from sperm cells is hampered by the enzyme's tendency to adsorb to cellular and other surfaces : enzyme lost from the acrosome may remain associated with the sperm cell. 
Another approach to the problem was suggested by the discovery that dispersion of acrosin and proacrosin from the acrosomal region can be followed by immunocytochemistry (Harrison, Fléchon and Brown, 1981). Using an ontibody to acrosin together with a fluorescein-conjugated anti-lgG, the acrosome of sperm heads that contain largely the zymogen form of acrosin are brightly labelled. But as activation of the proacrosin proceeds the labelling of the acrosome diminishes; this is associated with relocation of acrosin and proacrosin on other parts of the sperm cell. Because anti-acrosin antibody will react with proacrosin and acrosin alike and because the actual cellular location of the enzyme can be observed directly, the immunocytochemical technique may overcome at least two of the difficulties associated with biochemical estimations of acrosin loss.

In this paper we demonstrate that after cold shock, a treatment known to damage spermatozoa and cause loss of intracellular enzymes (Pursel, Johnson and Gerrits, 1970 ; Harrison and White, 1972 ; Roychoudhury, Pareek and Gowda, 1974), the acrosomal region of most spermatozoa is no longer strongly labelled with anti-acrosin. We compare this immunocytochemical method of assessing seminal acrosin with a biochemical method and we compare the «acrosin » assessment with a « live-dead» assessment.

\section{Materials and methods.}

Semen was obtained from 5 Suffolk rams, 1 Hereford and 2 Friesian bulls, and 3 cross-bred boars. Anti-acrosin serum was raised in rabbits by a single multiple-site injection of a 1:1 mixture of antigen solution with Freund's Complete Adjuvant ; the antigen used was purified ram acrosin that had been inhibited with di-isopropylfluorophosphate (Brown and Hartree, 1978), and a total of $600 \mu \mathrm{g}$ was injected into each animal. The serum, collected when antibody titre was maximal (about 6 wks after injections), was tested for specificity according to Fléchon et al. (1977). Fluoresceinconjugated sheep anti-rabbit $\mathrm{gg}$ and peroxidase-conjugated goat anti-rabbit $\mathrm{IgG}$ were from Miles Laboratories.

\section{Cold-shock procedure.}

Semen samples were diluted at $30^{\circ} \mathrm{C}$ with $150 \mathrm{mM}-\mathrm{NaCl}, 5 \mathrm{mM}$-glucose, $10 \mathrm{mM}$ HEPES $\mathrm{pH} 7.4$ to approximately $3 \times 10^{8}$ cells $/ \mathrm{ml} .1 \mathrm{ml}$ aliquots in thin-walled glass tubes were either incubated for $35 \mathrm{~min}$ at $30^{\circ} \mathrm{C}$ ( « controls »), or were incubated for $5 \mathrm{~min}$ at $30^{\circ} \mathrm{C}$, cooled rapidly in ice-water to $0{ }^{\circ} \mathrm{C}$ for $10 \mathrm{~min}$, and then further incubated at $30^{\circ} \mathrm{C}$ for $20 \mathrm{~min}$ (《 cold-shocked »).

\section{Cytochemistry.}

Immedialely after cold-shock treatment, duplicate subsamples from each tube were diluted $1: 1$ with nigrosin-eosin stain solution and smears made for «live-dead » estimations according to Dott and Foster (1972). At the same time other subsamples were diluted $1: 1$ with $150 \mathrm{mM}-\mathrm{NaCl}, 1 \mathrm{mM}$-p-aminobenzamidine from which several duplicate smears were made for immunocytochemistry.

Staining for acrosin was carried out according to the following procedure (Harrison, Fléchon and Brown, 1981). The air-dried smears were preincubated unfixed 
for $15 \mathrm{~min}$ with 3 p. $100 \mathrm{v} / \mathrm{v}$ sheep non-immune serum and $0.5 \mathrm{mM}$ p-aminobenzamidine in $250 \mathrm{mM}$-sucrose, $20 \mathrm{mM}$-phosphate $\mathrm{pH}$ 7.0. They were then incubated for $30 \mathrm{~min}$ with 3 p. $100 \mathrm{v} / \mathrm{v}$ rabbit anti-acrosin serum in sucrose phosphate containing 0.5 p. $100 \mathrm{v} / \mathrm{v}$ sheep non-immune serum (no p-aminobenzamidine present), and, after rinsing 3 times in serum-free sucrose medium, were further incubated for 30 min with 4 p. $100 \mathrm{v} / \mathrm{v}$ fluorescein-conjugated sheep anti-rabbit immunoglobulin in sucrose phosphate containing 0.5 p. $100 \mathrm{v} / \mathrm{v}$ sheep non-immune serum. All incubations were carried out in a moist chamber, in the dark at room temperature. Finally the smears were rinsed twice in sucrose phosphate $\mathrm{pH} 7.0$ and then once in sucrose phosphate $\mathrm{pH} 8.0$, and were mounted wet in glycerol for observation. In addition, duplicate smears were stained using 2 p. $100 \mathrm{v} / \mathrm{v}$ peroxidase-labelled goat anti-rabbit IgG in place of the fluorescein conjugate (goat non-immune serum was then used throughout the staining procedure in place of sheep non-immune serum). The peroxidase-labelled smears were stained for $8 \mathrm{~min}$ in 0.01 p. $100 \mathrm{w} / \mathrm{v}$ diaminobenzidine, $0.003 \mathrm{p} .100 \mathrm{w} / \mathrm{v} \mathrm{H}_{2} \mathrm{O}_{2}$ in $150 \mathrm{mM}$ tris $\mathrm{HCl} \mathrm{pH} 7.5$, rinsed with $\mathrm{H}_{2} \mathrm{O}$ air-dried and mounted using an acrylic mountant.

The concentrations of antisera used were selected following preliminary trials, to yield easily assessable staining of the acrosome without appreciable background staining.

All slides were coded and randomized, and were examined by two independent observers. All types of smear were observed by direct transmitted light ; a UV source with suitable exciter and barrier filters was used for the fluorescent smears. "Livedead » smears were scored for eosinophilic and non-eosinophilic cells; immunofluorescent smears were scored for «strongly», " moderately», and " weakly» stained sperm heads; immunoperoxidase smears were scored for «strongly», «moderately », «weakly » and « un-» stained heads. A total of at least one hundred sperm heads was scored in each smear by each observer, and the scores converted to percentages.

\section{Biochemical assessment of acrosin and proacrosin distribution.}

The method was based upon the work of Brown and Harrison (1978) and Harrison and Brown (1979). Immediately after cold-shock treatment, $0.5 \mathrm{ml}$ from each tube was layered on to $2.5 \mathrm{ml} 275 \mathrm{mM}$-sucrose, $0.5 \mathrm{mM}$-p-aminobenzamidine and centrifuged at $600 \mathrm{~g}_{\max }$ for $5 \mathrm{~min}$ followed by $2500 \mathrm{~g} \max$ for $10 \mathrm{~min}$. After centrifugation, a sample of the top layer was removed (the extracellular fluid of the treated semen samples). The rest of the top layer and most of the lower liquid layer was removed and discarded, to leave a total of approx. $0.5 \mathrm{ml}$ of sperm pellet and liquid, which was then resuspended thoroughly and acidified with approximately $3 \mu \mathrm{lof} \mathrm{M}-\mathrm{HCl}$ to a $\mathrm{pH}$ of 2.6-3.0. The suspension was left in ice for $30 \mathrm{~min}$ during which time it was whirlimixed twice; the acid extract was removed after high-speed centrifugation. Samples of the suspension were taken prior to centrifugation to assess the sperm density (haemocytometrically).

The extracellular fluid was assayed for active acrosin as follows : a $50 \mu \mathrm{l}$ sample was mixed with $1.1 \mathrm{ml} \mathrm{H}_{2} \mathrm{O}$ and acidified with approximately $3 \mu \mathrm{M}-\mathrm{HCl}$ to $\mathrm{pH}$ 2.6-3.0 ; it was left for $15 \mathrm{~min}$ at $25^{\circ} \mathrm{C}$ and then $0.15 \mathrm{ml}$ of $10 \mathrm{mM}$-benzoyl-arginine ethyl ester (BAEE) in $\mathrm{H}_{2} \mathrm{O}$ was added followed immediately by $0.3 \mathrm{ml}$ of $1 \mathrm{M}-\mathrm{CaCl}_{2}, 0.25 \mathrm{M}$-tris $\mathrm{HCl} \mathrm{pH} 8.2$ to which $10 \mu \mathrm{l}-\mathrm{NaOH} / \mathrm{ml}$ had been added; the change in extinction at 
$259 \mathrm{~nm}$ was then followed at $25^{\circ} \mathrm{C}$. The acid extract of the spermatozoa was assayed for active acrosin similarly by diluting a sample with $\mathrm{H}_{2} \mathrm{O}$ to $1.1 \mathrm{ml}$ and then adding

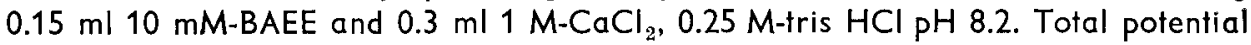
acrosin activity (proacrosin + active acrosin) was estimated as follows : a $50 \mu \mathrm{l}$ sample

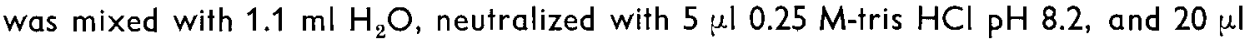
added of thermolysin solution ( $4 \mathrm{mg} / \mathrm{ml}$ Sigma Protease type (X) in $0.2 \mathrm{M}-\mathrm{CaCl}_{2}$, $0.05 \mathrm{M}$-tris $\mathrm{HCl} \mathrm{pH} \mathrm{8.2)} \mathrm{;} \mathrm{after} \mathrm{incubation} \mathrm{for} 20 \mathrm{~min}$ at $25^{\circ} \mathrm{C}$ to activate any proacrosin present, the mixture was acidified with $3.5 \mu \mathrm{M}-\mathrm{HCl}$ and left for a further $15 \mathrm{~min}$; finally $0.15 \mathrm{ml} 10 \mathrm{mM}$-BAEE was added, together with $0.3 \mathrm{ml} 1 \mathrm{M}-\mathrm{CaCl}_{2}, 0.25 \mathrm{M}$-tris $\mathrm{HCl} \mathrm{pH} 8.2$ containing $12 \mu \mathrm{M}-\mathrm{NaOH} / \mathrm{ml}$ and the change in extinction at $259 \mathrm{~nm}$ was followed at $25^{\circ} \mathrm{C}$. Acidification prior to addition of BAEE is necessary to dissociate the acrosin from seminal acrosin inhibitors present (Polakoski, Zaneveld and Williams, 1971). However thermolysin requires a neutral $\mathrm{pH}$ for its action (Matsubara and Feder, 1971).

\section{Results.}

The cytochemical observations are set out in tables $1-3$. The most obvious finding was that cold shock abolished the intense anti-acrosin-mediated fluorescent staining of the acrosome of all but a very few spermatozoa in all three species (see figs. 1 and 2). Each sperm cell exhibited an «all-or-none» appearance : either the acrosome was bright and strongly contrasted with the rest of the head, or it was not contrasted at all. Although absolute intensity of staining varied occasionally between fields due to uneven distribution of staining fluids, such variations did not affect the ease of scoring, and no cells were assigned a «moderately-stained » score. The repeatability of the immunofluorescent staining method was high both between observers and between duplicate slides.

While a similar trend of abolition of acrosome staining was easily delectable in the peroxidase-stained slides, the immunoperoxidase method was quantitatively less satisfactory because the resultant staining was less consistent and less uniform (see figs. 3 and 4). Repeatability was not good, either between duplicate slides or between observers (difficulties were experienced in distinguishing between the various catego-

FIG. 1. - Control sample of ram semen, stained for acrosin by immunocyfofluorescence. Almost all the spermatozoa have a brightly stained acrosome, but note the presence of one « unstained》 spermatozoon. The comparative intensity of « stained" and « unstained " cells is clear-cut.

FIG. 2. - Cold-chocked somple of ram semen, stained for acrosin by immunocytofluorescence. The majority of spermatozoa are now « unstained », but a few with bright acrosomes persist.

FIG. 3. - Control sample of bull semen, stained for acrosin by immunoperoxidase. Note the variation between spermatozoa in intensity of acrosomal staining.

FIG. 4. - Cold-shocked sample of bull semen, stained for acrosin by immunoperoxidase. In this field intensity of staining and variation between spermatozoa is similar to a control sample.

All $\times 480$. 


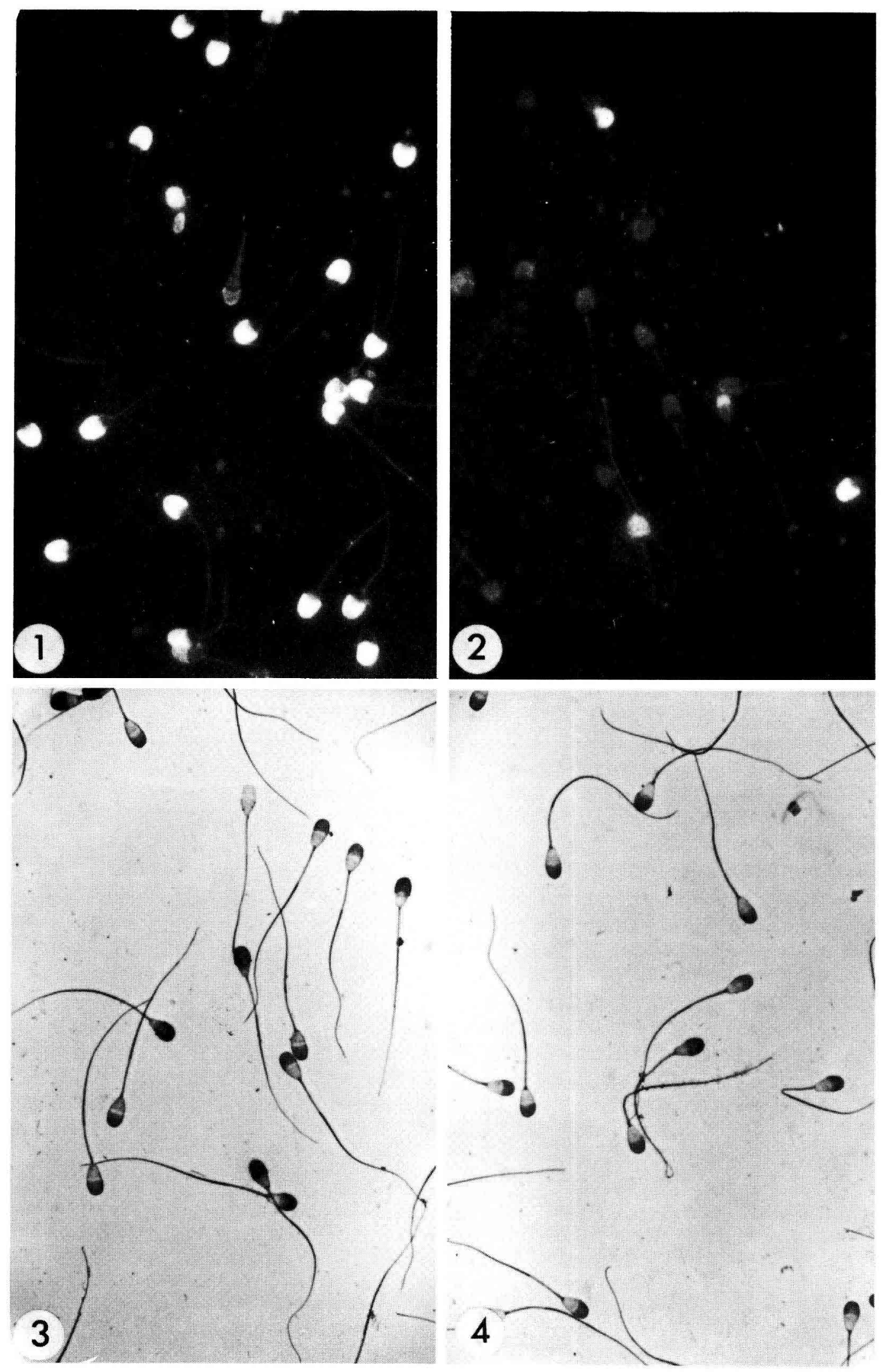


ries). Attempts to overcome the problem by varying the staining conditions were unsuccessful. The figures given in tables $1-3$ are those relating to the "strongly stained 》 category only, and do not show the variation between the « weakly stained » and the « moderately stained » categories.

\section{TABLE 1}

Response of ram spermatozoa to acrosin-specific immunofluorescent staining, acrosin-specific immunoperoxidase staining, and nigrosin-eosin staining : effect of cold shock

\begin{tabular}{ccccc}
\hline Animal & Treatment & $\begin{array}{c}\text { Immunofluorescence } \\
\text { (p. 100 strongly stained) }\end{array}$ & $\begin{array}{c}\text { Immunoperoxidase } \\
\text { (p. 100 strongly stained) }\end{array}$ & $\begin{array}{c}\text { Nigrosin-Eosin } \\
\text { (p. 100 unstained) }\end{array}$ \\
\hline \multirow{2}{*}{ I } & Control & $90.0 \pm 4.7$ & $50.8 \pm 24.4$ & $59.5 \pm 6.1$ \\
& Shocked & $2.5 \pm 1.0$ & $5.3 \pm 4.5$ & $0.5 \pm 0.6$ \\
II & Control & $87.3 \pm 4.5$ & $57.0 \pm 25.4$ & $58.3 \pm 11.5$ \\
& Shocked & $6.5 \pm 4.4$ & $3.5 \pm 2.6$ & $1.0 \pm 0.0$ \\
III & Control & $85.3 \pm 4.0$ & $57.0 \pm 12.5$ & $60.0 \pm 4.6$ \\
& Shocked & $4.8 \pm 2.1$ & $0.5 \pm 0.6$ & $4.3 \pm 2.5$ \\
\hline
\end{tabular}

Results are expressed as the mean \pm SD of 4 observations (2 duplicate slides, 2 observers).

TABLE 2

Response of bull spermatozaa to acrosin-specific immunofluorescent staining, ocrosin-specific immunoperoxidase staining, and nigrosin-eosin staining : effect of cold shock

\begin{tabular}{ccccc}
\hline Animal & Treatment & $\begin{array}{c}\text { Immunofluorescence } \\
\text { (p. 100 strongly stained) }\end{array}$ & $\begin{array}{c}\text { Immunoperoxidase } \\
\text { (p. 100 strongly stained) }\end{array}$ & $\begin{array}{c}\text { Nigrosin-Eosin } \\
\text { (p. 100 unstained) }\end{array}$ \\
\hline \multirow{2}{*}{ I } & Control & $60.8 \pm 9.4$ & & \\
& Shocked & $4.3 \pm 1.7$ & $57.5 \pm 20.3$ & $74.3 \pm 4.0$ \\
II & Control & $69.5 \pm 8.4$ & $3.0 \pm 1.8$ & $4.0 \pm 3.2$ \\
& Shocked & $4.5 \pm 1.3$ & $55.5 \pm 27.8$ & $80.8 \pm 4.6$ \\
III & Control & $66.3 \pm 13.6$ & $5.0 \pm 6.4$ & $2.3 \pm 1.0$ \\
& Shocked & $11.8 \pm 2.2$ & $52.5 \pm 36.8$ & $60.3+4.6$ \\
& & & $22.3 \pm 32.4$ & $2.5 \pm 1.3$ \\
\hline
\end{tabular}

TABLE 3

Response of boar spermatozoa to acrosin-specific immunofluorescent staining, acrosin-specific immunoperoxidase staining, and nigrosin-eosin staining : effect of cold shock

\begin{tabular}{ccccc}
\hline Animal & Treatment & $\begin{array}{c}\text { Immunofluorescence } \\
\text { (p. 100 strongly stained) }\end{array}$ & $\begin{array}{c}\text { Immunoperoxidase } \\
\text { (p. 100 strongly stained) }\end{array}$ & $\begin{array}{c}\text { Nigrosin-Eosin } \\
\text { (p. 100 unstained) }\end{array}$ \\
\hline \multirow{2}{*}{ I } & Control & $99.3 \pm 1.0$ & $94.5 \pm 3.7$ & $53.5 \pm 5.3$ \\
& Shocked & $0 \pm 0$ & $29.5 \pm 30.6$ & $1.5 \pm 1.3$ \\
II & Control & $99.0 \pm 0.8$ & $79.5 \pm 22.5$ & $11.3 \pm 4.6$ \\
& Shocked & $0 \pm 0$ & $0 \pm 0$ & $0.0 \pm 0.0$ \\
III & Control & $98.0 \pm 0.8$ & $94.8 \pm 4.6$ & $57.3 \pm 8.0$ \\
& Shocked & $0 \pm 0$ & $0 \pm 0$ & $3.5 \pm 1.3$ \\
\hline
\end{tabular}


As is well documented, cold shock caused a great decrease in the number of noneosinophilic ( « live ») cells ; repeatability was good both between observers and between duplicate slides. However there appeared more variation between semen samples (before cold shock) on the basis of «live-dead » estimations than on the basis of the immuno-fluorescence results.

Biochemical estimations of proacrosin activation in spermatozoa and loss of (pro) acrosin to the seminal plasma were performed on ram semen samples only (the samples were not the same as those in table 1). Results are shown in table 4 . There was a clearcut activation of proacrosin following cold shock, and a considerable loss of acrosin from the sperm cells to the surrounding fluid; but, when compared quantitatively to the immunofluorescent results, the changes were not as complete and varied considerably between samples.

\section{TABLE 4}

Distribution of acrosin and proacrosin in spermolozoa and seminal plasma of ram : effect of cold shock

\begin{tabular}{|c|c|c|c|c|}
\hline Animal & Treatment & $\begin{array}{c}\text { Total enzyme } \\
\text { in spermatozoa }\left({ }^{1}\right) \\
\text { (p. } 100 \text { activated) }\end{array}$ & $\begin{array}{c}\text { Total enzyme } \\
\text { in seminal plasma }\left({ }^{1}\right) \\
\text { (p. } 100 \text { activated) }\end{array}$ & Motility \\
\hline $\begin{array}{l}\text { I } \\
\text { II } \\
\text { III } \\
\text { IV } \\
\text { V }\end{array}$ & $\begin{array}{l}\text { Control } \\
\text { Shocked } \\
\text { Control } \\
\text { Shocked } \\
\text { Control } \\
\text { Shocked } \\
\text { Control } \\
\text { Shocked } \\
\text { Control } \\
\text { Shocked }\end{array}$ & $\begin{array}{r}14.3(7.5 \text { p. } 100) \\
7.8(51.1 \text { p. } 100) \\
12.5(17.4 \text { p. } 100) \\
6.6(42.1 \text { p. } 100) \\
13.8(15.0 \text { p. } 100) \\
4.9(53.2 \text { p. } 100) \\
13.3(8.2 \text { p. } 100) \\
7.1(44.6 \text { p. } 100) \\
12.3(11.2 \text { p. } 100) \\
10.5(46.1 \text { p. } 100)\end{array}$ & $\begin{array}{r}3.8(69.0 \text { p. } 100) \\
14.2 \text { (75.6 p. } 100) \\
9.5(72.9 \text { p. } 100) \\
18.1(78.5 \text { p. } 100) \\
7.0(79.9 \text { p. } 100) \\
19.8(75.0 \text { p. } 100) \\
4.5(71.9 \text { p. } 100) \\
16.2(74.4 \text { p. } 100) \\
4.7 \text { (79.0 p. } 100) \\
11.5 \text { (70.0 p. } 100)\end{array}$ & $\begin{array}{l}\text { Good } \\
\text { Nil } \\
\text { Moderate } \\
\text { Nil } \\
\text { Moderate } \\
\text { Nil } \\
\text { Moderate } \\
\text { Nil } \\
\text { Very good } \\
\text { Nil }\end{array}$ \\
\hline
\end{tabular}

(1) Units of activity after thermolysin activation $/ 10^{9}$ spermatozoa (seminal plasma values have been related to the sperm concentration in the semen).

* Active acrosin Total acrosin $\vee 100$ p. 100

In preliminary experiments on bull and boar material, estimations of acrosin and proacrosin in seminal plasma were unsatisfactory and inconsistent, probably due to interference by the very high levels of acrosin inhibitor activity present. Therefore no biochemical estimations of acrosin loss following cold shock were made on these species.

\section{Discussion.}

Our results show clearly that after cold shock both acrosin and its zymogen proacrosin are released from spermatozoa into the surrounding seminal plasma. The finding is not unexpected in view of the acrosomal location of the enzyme within the sperm cell (see Harrison, Fléchon and Brown, 1981) and the damage that cold shock is known to cause to the acrosome (Quinn, White and Cleland, 1969 ; Pursel, Johnson and Rampacek, 1972). It does confirm our belief (Harrison, Fléchon and Brown, 1981) in the essentially soluble nature of (pro) acrosin under quasi-physiological conditions. 
Similar observations with respect to release of active acrosin into extracellular fluid were made by Schill and Fritz (1975) when human semen was aged in vitro, though the authors drew no conclusions regarding the enzyme's «solubility ».

However, despite the efforts we made to take account of the complexities of the proacrosin-acrosin-inhibitor systems in semen, the quantitative results obtained from the biochemical estimations were less than satisfactory. Although there was a considerable increase in the acrosin activity in seminal plasma, much of the active acrosin remained associated with the spermatozoa ; from other studies (Brown and Harrison, 1978), it is known that such acrosin must derive from damaged acrosomes. Also, the total potential acrosin activity of the cold-shocked samples (spermatozoa + seminal plasma) was consistently higher than the control samples, possibly because the presence of protein acrosin inhibitor in the undamaged control spermatozoa (Brown and Hartree, 1975) may have reduced the thermolysin activation of proacrosin to give low total values.

The discovery that cold-shock treatment abolished the intense staining of the acrosome obtained via anti-acrosin treatment of smears of intact cells is in accord with our recent conclusions regarding the location and behaviour of proacrosin and acrosin in spermatozoa (Harrison, Fléchon and Brown, 1981). We believe that proacrosin is located entirely within the acrosomal matrix in an intact spermatozoon. When the acrosome is disrupted (e.g. by cold shock), proacrosin activation begins, and the acrosin produced disperses (together with unchanged proacrosin). The concentration of the (pro) acrosin antigen in the acrosomal region thereby decreases greatly, whence the immunocytochemical staining of that region is also greatly decreased.

Compared with the biochemical method, the immunocylochemical method of estimation of acrosin loss has a number of theoretical advantages. Firstly, because the antiserum against acrosin cross-reacts with proacrosin (R. A. P. Harrison, in preparation), all the species of acrosin can be defected simultaneously, most importantly the proacrosin species found within the acrosome; the presence of seminal acrosin inhibitors does not appear to interfere. Secondly, the acrosomal region is actually observed directly and therefore the tendency of released acrosin to readsorb to other cell surfaces does not interfere, because the intensity of staining of the acrosomal region is in any case greatly diminished. Thirdly, the immunocytochemical method has the considerable advantage of enabling observations to be made of individual cells, when the homogeneity or otherwise of the population can be assessed ; normal biochemical assay methods cannot distinguish between situations in which all cells are of moderate quality and situations in which some of the population are normal while the rest are of very poor quality. The fluorescent immunocytochemical method has advantages over the biochemical method from a practical standpoint also. It is simpler, and more importantly the apparent response to damage is much greater : biochemical estimations showed some 15 p. 100 of the proacrosin to be associated with shocked ram sperm cells (i.e. 15 p. 100 of the cells were apparently intact), whereas immunofluorescence showed that only 2-3 p. 100 of the cold-shocked cells retained acrosomes that were intensely stainable.

The reasons for the inconsistent results obtained using the peroxidase-conjugated anti-lgG are unclear. We suspect that it is the peroxidase system which is at fault, and 
that the results are not a true reflection of the status of the acrosome. In certain instances staining was less complete than might have been expected (by comparison with the fluorescent system), while in others staining was greater than expected. The discrepancies may be due to a combination of the greater sensitivity of the peroxidase detection system, problems of substrate access in regions of high peroxidase activity, difficulties in standardizing the stain conditions, and the extra steps required to perform the stain.

Although the results of the immunofluorescent staining were overall in good agreement with those of nigrosin-eosin staining, there were some quantitative discrepancies between them with respect to the values obtained for individual «control » semen samples : usually, there were more «intact » cells by immunofluorescence than were "live » by nigrosin-eosin stain. This is not surprising, because the two parameters assessed are not (so far as is known) connected. In this study a simultaneous assessment of acrosomal damage by morphological methods (e.g. Watson, 1975 ; Jones and Stewart, 1979) was not attempted. However, we believe that an immunofluorescent cytochemical method of assessing acrosomal damage via enzyme content of individual cells may offer a useful and relevant parameter for semen quality, and warrants evaluation in parallel with other methods of semen analysis.

Reçu en février 1980

Accepté en mai 1980.

Acknowledgments. - We thank Mr. Dale Wigley for skilful technical assistance.

Résumé. Des échantillons de sperme de bélier, taureau ef verrat ayant subi un choc thermique sont soumis à un traitement immunocytochimique de détection de l'acrosine. Le choc thermique abolit la coloration spécifique de l'acrosome dans la plupart des spermatozoïdes, ce qui est interprété comme une perte massive de proacrosine ou d'acrosine à la suite de dommages acrosomiques. Les résultats sont établis en utilisant la fluorescéine comme marqueur du $2^{\mathrm{e}}$ antisérum dans la méthode indirecte. La reproductibilité est moins bonne si l'on utilise la peroxydase comme marqueur à cause de plus grandes difficultés de standardisation de la technique.

Le dosage biochimique de l'acrosine du sperme avant et après choc thermique confirme le passage, dans ce dernier cas, d'acrosine des spermatozoïdes dans le plasma séminal. Cependant la méthode biochimique ne peut pas donner une estimation quantitative de l'intégrité cellulaire comparable à l'immunocytochimie. Une comparaison avec une coloration des spermatozoïdes morts/vivants est présentée.

\section{References}

BROWN C. R., HARRISON R. A. P., 1978. The activation of proacrosin in spermatozoc from ram, bull and boar. Biochim. biophys. Acta, 526, 202-217.

BROWN C. R., HARTREE E. F., 1975. An acrosin inhibitor in ram spermatozoa that does not originate from the seminal plasma. Hoppe-Seyl. Z. Physiol. Chem., 356, 1909-1913.

BROWN C. R., HARTREE E. F., 1978. Studies on ram acrosin. Activation of proacrosin accompanying the isolation of acrosin from spermatozoa and purification of the enzyme by affinity chromatography. Biochem. J., 175, 227-238. 
CHURCH K. E., GRAVES C. N., 1976. Loss of acrosin from bovine spermatozoa following cold shock : protective effects of seminal plasma. Cryobiology, 13, 341-346.

DOTT H. M., FOSTER G. C., 1972. A technique for studying the morphology of mammalian spermatozoa which are eosinophilic in a differential "live-dead " stain. J. Reprod. Fert., 29, 443-445.

FLÉCHON J. E., HUNEAU D., BROWN C. R., HARRISON R. A. P., 1977. Immunocytochemical localization of acrosin in the anterior segment of the acrosomes of ram, boar and bull spermatozoa. Ann. Biol. anim. Bioch. Biophys., 17, 749-758.

HARRISON R. A. P., BROWN C. R., 1979. The zymogen form of acrosin in testicular, epididymal, and ejaculated spermatozoa from ram. Gamete Res., 2, 75-87.

HARRISON R. A. P., FLÉCHON J. E., BROWN C. R., 1981. The localisation of acrosin and proacrosin in ram spermatozoa. J. Reprod. Fert., accepted for publication.

HARRISON R. A. P., WHITE I. G., 1972. Glycolytic enzymes in the spermatozoa and cytoplasmic droplets of bull, boar and ram, and their leakage after shock. J. Reprod. Fert., 30, 105-115.

JOHNSON L. A., PURSEL V. G., CHANEY N., 1974. Boar spermatozoa acrosomal proteinase loss during freezing. J. Anim. Sci., 39, 213-214.

JONES R. C., STEWART D. L., 1979. The effects of cooling to $5{ }^{\circ} \mathrm{C}$ and freezing and thawing on the ultrastructure of bull spermatozoa. J. Reprod. Fert., 56, 233-238.

MATSUBARA H., FEDER J., 1971. Other bacterial, mold, and yeast proteases. In BOYER P. D., The enzymes 3rd Ed. Vol. III, Ch. 20, 721-795. Acad. Press, New York.

POLAKOSKI K. L., ZANEVELD L. J. D., WILLIAMS W. L., 1971. An acrosin-acrosin inhibitor complex in ejaculated boar sperm. Biochem. Biophys. Res. Commun., 45, 381-386.

PURSEL V. G., JOHNSON L. A., GERRITS R. J.,1970. Distribution of glutamic oxalacetic transaminase and lactic dehydrogenase activities in boar semen after cold shock and freezing. Cryobiology, $7,141-144$.

PURSEL V. G., JOHNSON L. A., RAMPACEK G. B., 1972. Acrosome morphology of boar sperm incubated before cold shock. J. anim. Sci., 4, 278-283.

QUINN P. J., WHITE I. G., CLELAND K. W., 1969. Chemical and ultrastructural changes in ram spermatozoa after washing, cold shock and freezing. J. Reprod. Fert., 18, 209-220.

ROYCHOUDHURY P. N., PAREEK P. K., GOWDA H. C., 1974. Effect of cold shock on glutamic oxaloacetic transaminase (GOT) and glutamic pyruvic transaminase (GPT) release from bull and ram spermatozoa. Andrologia, 6, 315-319.

SCHILL W.-B., FRITZ H., 1975. N $\alpha$-benzoyl-L-arginine ethyl ester splitting activity (acrosin) in human spermatozoa and seminal plasma during aging in vitro. Hoppe-Seyl. Z. Physiol. Chem., 356, 83-90.

WATSON P. F., 1975. Use of a Giemsa stain to detect changes in acrosomes of frozen ram spermatozoa. Vet. Rec., 97, 12-15. 